\title{
Effectiveness of Football Hold Position Breastfeeding Techniques and Upright Position on Decreasing Regurgitation Frequency Newborn
}

\author{
$1^{\text {st }}$ Vera Iriani Abdullah \\ Department of Midwifery \\ Polytechnic of the Ministry of Health, Sorong \\ Sorong City, Indonesia \\ verabdullah1977@gmail.com
}

\author{
$2^{\text {nd }}$ Hajrah Azizah \\ Department of Midwifery \\ Polytechnic of the Ministry of Health, Sorong \\ Sorong City, Indonesia \\ hazrahazizah6@gmail.com
}

Corresponding author: verabdullah1977@gmail.com

\begin{abstract}
Regurgitation experienced by babies more than 4 times a day has a 2 times greater likelihood of experiencing malnutrition compared to infants who have regimens less than 4 times a day. The purpose of this study was to determine the effectiveness of football hold position breastfeeding techniques and upright position against the decrease in the frequency of regurgitation in newborns. This research is a pre-experimental design with the one group pretest-posttest design approach. The population in this study were all newborns. Sampling uses the Simple Random Sampling method with a sample of 31 newborns aged 0-28 days who have sucking and swallowing (+) reflexes. Data collection using observation sheets using Wilcoxon Test analysis. The technique of breastfeeding football hold position is done for $15-30$ minutes. After breastfeeding the baby is positioned in an upright position for 30 minutes. Observations are carried out for 3 days. Based on the results of the Wilcoxon Test analysis using SPSS shows that the value of $p 0,000$ is smaller than 0.05 . So it was concluded that football hold positions breastfeeding techniques and upright positions were more effective in reducing the Frequency of regurgitation in Newborns InSele Be Solu Hospital In 2019.
\end{abstract}

Keywords: Football Hold Position, Upright Position, Regurgitation, breastfeeding, newborn.

\section{INTRODUCTION}

Football hold position is a position where the mother sits in a comfortable position, the baby lies on her back, the baby curls between the chest and mother's arms, the baby's upper body is supported by the mother's forearm, the mother's hand supports the baby's neck, baby's hips flex at the back chairs or other surfaces where you lean [1]. While the upright position technique is an upright position. According to Aydogan (2014) normal regurgitation which is $\langle 4 x /$ day, the frequency of regurgitation $>4 \mathrm{x} /$ day will increase 2 times the baby experiences malnutrition [2].

Regurgitation occurs is increase in infants such as premature, sepsis / infection, neurological, brain and muscle abnormalities. [3]. However, it does not rule out the possibility of mature babies contributing to the incidence of regurgitation. That is because the ability of newborns to swallow and digest food (other than milk) is still limited. The relationship between the lower esopagus and the stomach is still incomplete resulting in regurgitation in the newborn. Gastric capacity is still limited, less than $30 \mathrm{cc}$ for term newborns [4]. In Europe around $60-80 \%$ of regurgitation occurs in healthy infants aged 0-1 months at least 1 time a day. Regurgitation in infants will decrease by $40-60 \%$ at ages 4 - 6 months, and $4-5 \%$ at 12 months and above. Regurgitation peaked at 4 months at $67 \%$ and decreased by $36 \%$ at 8 months. In Indonesia $70 \%$ of infants under 4 months had regurgitation at least once a day with a regurgitation volume of more than $5 \mathrm{ml}$. Excessive regurgitation 
becomes pathological ecause stomach acid flows into the esophagus, the lining of the esophagus damages resulting in esophagitis, resulting in a fussy baby due to pain in the throat [5].

The results of a preliminary study conducted by researchers in January 2019 at Sele Be Solu Hospital in Sorong City showed that the number of neonatal deaths in 2018 was 12 people. The cause of death is due to Extreme Low Birth Weight of 50\%, LBWR (Very Low Birth Weight) of $8.3 \%$, LBW (Low Birth Weight) of $8.3 \%$, severe asphyxia of $16.7 \%$, sepsis of $8.3 \%$, a nd major congenital (congenital defect) abnormalities of $8.3 \%$. Interviews conducted on 6 postpartum women at Sele Be Solu Hospital in Sorong City, 6 post SC mothers complained of difficulties in breastfeeding because if breastfeeding in the cradle hold position would press the wound area so that it would cause pain, 2 of 6 mothers said the frequency of regurgitation experienced the baby is 1-2 times / day while the other 4 mothers say the baby is not experiencing regurgitation.

Based on the above background, the previous journals [5] [4] and the importance of these problems, the authors are interested in conducting research to find out the effectiveness of football hold position breastfeeding and upright position techniques for decreasing the frequency of regurgitation in newborns in Sele Be Solu Hospital in Sorong City in 2019.

\section{METHODS}

This research is a pre-experimental design with the one group pretest-posttest design approach. The population in this study were all newborns. Sampling uses the Simple Random Sampling method with a sample of 31 newborns aged 0-28 days who have sucking and swallowing (+) reflexes. Swallowing reflexs is a collection of milk in the baby's mouth presses on the muscles in the mouth and pharynx area to activate the swallowing reflex and push the milk into the baby's stomach. Data collection using observation sheets. The observation sheet

contains the name of the respondent, the level of regurgitation before the intervention (pretest), then the intervention (postest) is carried out and then it is observed until the third day. Data analysis techniques using the SPSS for Windows program using the Wilcoxon test.

\section{RESULTS}

Table 1. The Result of Mean and Pretest-Posttest Standard Deviation

\begin{tabular}{llll}
\hline \multicolumn{2}{l}{ Before Intervention } & \multicolumn{2}{l}{ After Intervention } \\
\hline Mean & Std. & Average & Std. Deviation \\
& Deviation & & \\
& & &, 00000 \\
\hline 2,3548 & 1,25295 &, 0000 & \\
\hline
\end{tabular}

Source: Primary Data

Based on table 1 .Above it can be stated that the average frequency of regurgitation before intervention is 2 times per day. While the average frequency of regurgitation after giving intervention is, 0000. It means that there is no regurgitation.

Table 2. Ranks According to the Wilcoxon Test

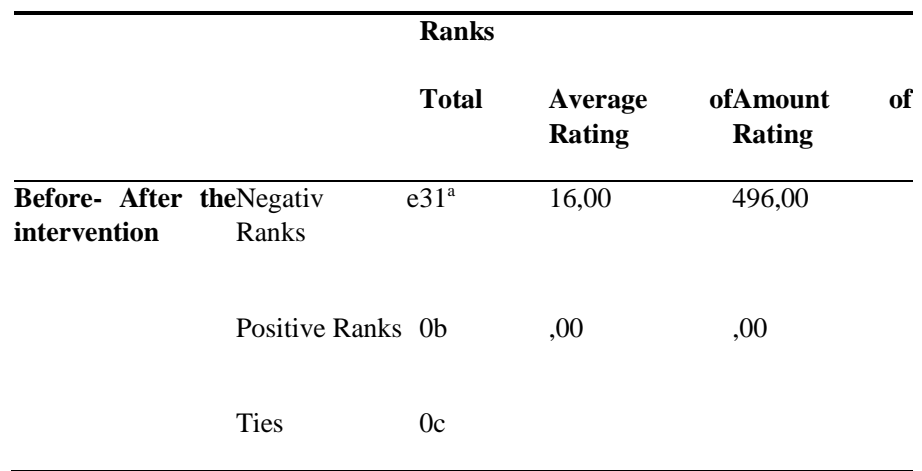

Source: Primary Data

Based on table 2. above it can be stated that according the data, negative ranks in here there are 31 negative data $(\mathrm{N})$ which means that for 31 newborns there is a decrease in the frequency of regurgitation from the value of the pretest to the posttest value. In positive ranks, this value of 0 shows no increase in the frequency of regurgitation from the regurgitation value of the pretest to the value of posttest regurgitation and ties value is 0 so that it can be said that there is no same value between the frequency of regurgitation pretest and posttest

Table 3. The Results of Wilcoxon Test

Before-After Intervention

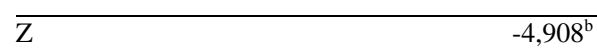

Asymp. Sig. (2-tailed) $\quad, 000$

Source: Primary Data 
Based on table 3 above, it is known that the $\mathrm{p}$ value is 0,000 less than 0.05 so the results of the above analysis stated that football hold positions breastfeeding techniques and upright positions are more effective in reducing the frequency of regurgitation in newborns in Sele Be Solu Hospital in 2019.

\section{DISCUSSION}

Based on the results of research carried out in the Sele Be Solu Regional Hospital of Sorong City, in 10-31 of March, 2019, it was stated that the technique of breastfeeding which is football hold position and upright position was effective in decreasing the frequency of regurgitation on birth. The results of this research were conducted with a study that conducted to 0-6 month-old babies in the village of Papar Village, Subdistrict, Sumobito, Jombang, which stated that there is technical contact relationship of breastfeeding and regurgitation event occurred to babies at 0-12 months. [6]. Other results conducted on breastfeeding mother who have babies aged 0-2 months at Health Center Harapan Raya, Riau stated that there is a relationship between the techniques of attachment and breastfeeding during the event of regurgitation in babies aged 0- 2 months [1].

Another study conducted on 6 babies aged 0-3 months in SemanggiVillage, Surakarta stated that the effect of giving an upright position was to reduce the frequency of gums. The percentage of success reached $62.5 \%$ [5]. This is also in line with the theory that the position of the football hold is the recommendation of breastfeeding position, because this position allows the baby to swallow breast milk easily when breastfeeding, can be used by a mother who has a large breast size because it will get a more breathing, and can be used by mother who has premature baby [7].

In addition, the results of this study were supported by a number of factors including age, job, education, baby's sex , baby's age, and baby's weight. In age factors, the majority of respondents regarding the early adult (26-35 years) amounted to 14 respondents $(45.2 \%)$.
Table 4. Characteristics of Respondents by Age

\begin{tabular}{llll}
\hline No & Age of respondents & Frequency & Percentage \\
\hline 1. & $\begin{array}{l}\text { Early teens (12- } \\
\text { 16 years) }\end{array}$ & 1 & 3,2 \\
\hline $\mathbf{2 .}$ & $\begin{array}{l}\text { Late teens (17- } \\
\text { 25 years) }\end{array}$ & 13 & 41,9 \\
\hline 3. & $\begin{array}{l}\text { Early Adulthood } \\
\text { (26-35 years) }\end{array}$ & 14 & 45,2 \\
\hline 4. & $\begin{array}{l}\text { Late Adulthood } \\
\text { (36-45 years) }\end{array}$ & 3 & 9,7 \\
\hline Total & 31 & 100,0 \\
\hline
\end{tabular}

The average respondent is 26,12 years old. The statistical results of Siswoyo (2011) [8] prove the influence between maternal and breastfeeding status. The more mature age will add maturity in attitude and action. Other than that, mother's age is very important in determining maternal health and related to the condition of pregnancy, childbirth, puerperal and the assertiveness of caring for and nursing the baby. This is in line which states that there is a meaningful relationship between maternal age and breastfeeding [9].

In job factors, the majority of unemployed respondents are 27 respondents $(87.1 \%)$. The results of the analysis found that the average work of the respondents who are unemployed (housewife), which means that they have to spend a lot of time to optimally breastfeed the baby. Housewives generally have more time in managing family health including in managing kids. This is in line study which states that the working status affects the coverage of breastfeeding. Imployed mothers tend to not provide exclusive breastfeeding because of the various reasons in which there is no time to give breast milk directly, heavy work time, work that is not compatible with the giving of breast milk Exclusion, the mothers don't know how to milk breastmilk, how to keep breastmilk and how to give breast milk [10].

In terms of the level of education, most of the respondents are high school / MA graduates, those are 18 respondents $(58.1 \%)$, this shows that the highest level of education of a person is broadening the way of thinking and responding to the information obtained. Mother can absorb a variety of good information through socialization, counseling and through media, so that more has an understanding of the importance of exclusive breastfeeding. The results of this states that the level of knowledge and education has a positive effect on the frequency and pattern of breastfeeding [11].

In this study, the highest number of infant sex factors was male, which is 21 male respondents $(67.7 \%)$. The development of boys tends to be faster than girls who endure until a certain age, given that girls will 
experience puberty first. This is also supported by the theory of Soetjiningsih and Ranuh (2016) stating that boys are more active than girls so that baby boys need more nutritious supplies than baby girls. This affects the intensity of breastfeeding and the pattern of breastfeeding [12].

In this study, the majority of baby's age factors are present (0-7 days) totaling 23 respondents (74.2\%) with an average age is 8.2581 days. The age of the baby will determine the maturity system because the newborn who's full-term the gastrointestinal system function properly although not optimally. This is supported by the theory of Saputra (2014) which states that the ability of newborns to be full term to swallow and digest (except milk) is still limited. The relationship between the lower esopagus and the stomach is still incomplete in acquiring spit on newborns [4].

Gastric capacity in newborns is still limited, which is less than $30 \mathrm{cc}$. On the 8th day gastric capacitance of $45-60 \mathrm{ml}$ or the size of a ping pong ball. So, the more mature the gastrointestinal system, the less likely it is to have regurgitation. Baby's weight is an important factor. In this study, of the 31 respondents overall had a normal birth weight $(100 \%)$ with an average of 2964.5161 grams. Birth weight has a large impact and influence on a baby's growth and development. Birth weight is one indicator in the growth and development of children until adulthood and describes the nutritional status obtained by the fetus during pregnancy. The results of this study are supported by the theory of Kosim et al (2008) which states that several determinant factors that potentially affect the birth weight of a baby include: maternal anthropometry, food intake (energy, protein, animal or vegetable food sources), socioeconomic status [13].

Regurgitation is actually a normal event, but excessive regurgitation can cause complications that will interfere with the growth of the baby if the fluid that comes out is not balanced with the fluid that enters the baby's body. This is states that babies who experience regurgitation more than 4 times a day are 2 times more likely to experience malnutrition compared tobabies who experience regugitation less than 4 times a day. This is consistent with the theory put forward by Hasibuan, Hegar, and Kadim (2012) which states that damage to the esophageal mucosa due to esophageal reflux in children is a condition that needs to be aware of in every child with clinical symptoms of regurgitation with excessive volume and frequency. Lake of the effectiveness of football hold position and upright position breastfeeding techniques to reduce the frequency of regurgitation in newborns. The basic thing that motivates researchers to conduct this research is to develop / making new theories in the field of midwifery. So that the results of this study can be new solutions and recommendations in handling cases of regurgitation in newborns [14].

\section{CONCLUSION}

Football hold positions breastfeeding techniques and upright positions are more effective in reducing the frequency of regurgitation in newborns in Sele Be Solu Hospital in 2019.

\section{REFERENCES}

[1] Bernadus KL, Lestari ID. Hubungan Antara Pengetahuan Ibu Tentang Cara Menyendawakan Bayi Usia $0-6$ Bulan Dengan Kejadian Gumoh Sesudah Menyusui Di Puskesmas Manukan Kulon 2010:12-6.

[2] Aydogan, Hakan, Abrakov, Azamat A. Teori Pembelajaran Anak Usia Sini, Bandung; PT. Remaja Rosdakarya; 2014.

[3] Rukiyah Y. Asuhan Neonatus Bayi Dan Anak Balita.2016.

[4] Saputra. Pengantar Asuhan Neonatus, Bayi dan Balita. 2016.

[5] Han ES, goleman, daniel; boyatzis, Richard; Mckee A. 済 無No Title No Title. J Chem Inf Model 2019;53:1689-99.

[6] Persentase Kelahiran Bayi Menurut Kabupaten / Kota Dan Penolong Kelahiran Terakhir Tenaga Medis 2007-2014. n.d.

[7] Susanto V. Asuhan Kebidanan Nifas dan Menyusui: Teori Dalam Praktik Kebidanan Profesional. 2018.

[8] Siswoyo D. Ilmu Pendidikan. Yogyakarta: UNY; 2008.

[9] Setiadi. Konsep dan Praktik Penulisan Riset Keperawatan. 2013.

[10] Swajarna. Metode Penelitian Kesehatan (EdisiRevisi). 2015.

[11] Kadir. Statistika Terapan:Konsep, Contoh dan Analisi Data dengan Program SPSS/Lisrel Dalam Penelitian. n.d.

[12] Soetjiningsih, IG.N GR. Tumbu Kembang Anak Edisi 2. Jakarta: Penerbit Buku Kedokteran; 2013.

[13] Rosim, M.Sholeh. Buku Panduan Menejemen Masalah Bayi Baru Lahir Untuk Dokter, Perawat, Bidan di Ruma Sakit Rujukan Dasar. MNH-JHPEGO Indones 2005; hh.10, 42-.

[14] Hasibuan B, Hegar B, Kadim M. Derajat Kerusakan Mukosa Esofagus pada Anak dengan Penyakit Refluks $\begin{array}{llll}\text { Gastroesofagus. } & \text { Sari } & \text { Pediatr } & \text { 2016;14:19. }\end{array}$ https://doi.org/10.14238/sp14.1.2012.19-23 